\title{
A thermometric study on the kinetics of the acid dissolution of aluminium in the presence of Napoleonaea imperialis seeds extract and iodide ions
}

\author{
Habibat Faith CHAHUL, ${ }^{1, *}$ Gloria Ihuoma NDUKWE, ${ }^{2}$ and David Ogwu OGWU ${ }^{1}$ \\ ${ }^{1}$ Department of Chemistry, Federal University of Agriculture, P.M.B. 2373 Makurdi, Benue State, Nigeria \\ ${ }^{2}$ Department of Chemistry, Rivers State University, Nkpolu-Oroworukwo, Port Harcourt, Rivers State, Nigeria
}

\begin{abstract}
The dissolution of aluminum alloy AA 1060 in $0.5 \mathrm{M}$ and $1.0 \mathrm{M} \mathrm{HCl}$ was investigated using thermometric measurements. The reaction number of the aluminum coupons varied linearly with the concentration of the acid. Addition of Napoleonaea imperialis seed extract to the dissolving aluminium coupons lowered the reaction number in both concentrations of $\mathrm{HCl}$ by inhibiting the dissolution process. The inhibition efficiency of Napoleonaea imperialis seed extract was enhanced to a considerable extent in the presence of iodide ions with the synergistic parameter $S>1$. The adsorption of Napoleonaea imperialis extract on the aluminium surface best aligned with the Langmuir adsorption isotherm model. The values of the free energy, $\Delta G_{\text {ads }}$, for the adsorption process revealed the process to be spontaneous and physisorptive.
\end{abstract}

Keywords: aluminium, temperature, reaction number, Napoleonaea imperialis, inhibition efficiency, adsorption isotherm.

\section{Introduction}

Metals and alloys have numerous applications in industrial installations and equipment, however these metals and alloys are often attacked by corrosion. Metals and alloys are prone to corrosion either by man-made fluids or by natural fluids [1-3]. These reactions may damage the metal simultaneously with consequent loss of cohesive strength. The surface of metallic structures is attacked through the migration of ions away from the surface, resulting in material loss over time [2-5].

According to ASM International 2012, aluminium is an important metal in many industries owing to its many excellent characteristics especially its good electrical and thermal conductivities, low density, high ductility, low cost and availability for the fabrication and construction industries. It is widely used as materials for automobiles, aviation, household appliances, containers, electronic devices, pipes, machinery, and chemical batteries $[6,3$ 5].

It has been reported that the oxide film on aluminium can readily undergo dissolution in chloride environments. Suitable inhibitors must be used if the life span of this valuable metal must be guaranteed. For this reason the corrosion mechanism of aluminium in chloride solutions has been investigated in a number of studies [7-14]. This has brought about the use of inhibitors which can counteract the corrosive action of such aggressive environments.

Corrosion inhibitors are chemical substances that when added in small concentration to an environment, effectively decreases the corrosion rate [15-20].

Though the use of inhibitors has been one of the best means of protecting metals and alloys against corrosion, however, most of these inhibitors are toxic to the environment [15-20]. In an attempt to find inhibitors which are environmentally friendly, safe and readily available, attention has been drawn to the use of natural products such as plant extracts as corrosion inhibitors [7, 10, 11, 13-16, 18-22]. Napoleonaea imperialis (NI) seed extract contains some saponins, alkaloids, glycosides and proteins [23]. These phytochemicals have structures similar to those of conventional corrosion inhibitors hence their potential to inhibit the corrosion of metals/alloys in corrosive environments.

This study sets to investigate the dissolution of aluminum in $\mathrm{HCl}$ in the presence of NI seeds extract and iodide ions using thermometric measurements.

\section{Experimental}

\subsection{Materials}

The reagents used in experiments were purchased from Emole Nigeria Limited, while the aluminium sheet, AA 1060 type and purity 98.5 per cent was obtained from Eastern Chase Aluminium Company, Avu Owerri, in Nigeria.

\subsection{Preparation of aluminium coupons}

The sheet of aluminium, AA 1060 type and purity 98.5 per cent used for this study was mechanically pressed cut into $3 \times 2 \mathrm{~cm}$ coupons. These coupons were used as cut without further polishing. However, they were degreased in ethanol, dried in acetone and stored in a moisture free desiccator before their use in the studies.

\subsection{Preparation of plant extract}

Fresh ripe fruits of NI were harvested from Obinze in Owerri Capital Territory, Imo State, Nigeria. The plant was identified and authenticated by Mr. J. Opayemi, Department of Plant Science \& Biotechnology, University of Port Harcourt and voucher sample, UPH 147, deposited at University of Port Harcourt Herbarium. The seeds were separated from their rinds and were air-

\footnotetext{
* Corresponding author. E-mail address: momohbat2007@gmail.com (Habibat Faith Chahul)
} 
dried, and then crushed to coarse powder at room temperature and weighed. $243 \mathrm{~g}$ of the coarse powder was extracted with $n$-butanol by cold maceration for 48 hours [23].

The process was repeated 5 times using fresh solvent each time. Extracts obtained were combined and concentrated to dryness using a rotary evaporator to yield $24.05 \mathrm{~g}$ of sticky dark brown extract.

\subsection{Preparation of inhibitor solution}

Five different concentrations of NI seed extract $(0.2 \mathrm{~g} / \mathrm{L}$, $0.4 \mathrm{~g} / \mathrm{L}, 0.6 \mathrm{~g} / \mathrm{L}, 0.8 \mathrm{~g} / \mathrm{L}$, and $1.0 \mathrm{~g} / \mathrm{L})$ were prepared in $0.5 \mathrm{M}$ and $1.0 \mathrm{M} \mathrm{HCl}$ solution respectively and were used for the measurements. A blank was also prepared without the inhibitor. The effect of iodide ions on the inhibition efficiency of NI extract was investigated by adding $5 \mathrm{mM}$ $\mathrm{KI}$ the different concentrations of NI extract $[8,9,13$, $18]$.

\subsection{Thermometric method}

The solutions of $\mathrm{HCl}$ were prepared by dilution of analytical grade $\mathrm{HCl}$ with distilled water and used as corrodent. The reaction vessel is a well lagged calorimeter to prevent heat losses. The corrodent solution was varied at $1.0 \mathrm{M}$ and $0.5 \mathrm{M}$, while the halide (KI) used had its concentration to be $0.001 \mathrm{M}, 0.002 \mathrm{M}, 0.003 \mathrm{M}$, $0.004 \mathrm{M}$ and $0.005 \mathrm{M}$ (for synergism) respectively. The volume of the test solution used was $100 \mathrm{~mL}$. The progress of the corrosion reaction was monitored by determining the changes in temperature with time (each minute for the first five minutes, each five minutes for the next twenty five minutes and each ten minutes for the last thirty minutes) using a calibrated thermometer (0 $100^{\circ} \mathrm{C}$ ) to the nearest $\pm 0.05^{\circ} \mathrm{C}$. The data was generated for a period of one hour. From the rise in temperature per minute, the reaction number $(R N)$ was calculated using Eq. 1 and $2[9,13,24]$ :

$$
R N\left(\mathrm{~K} \cdot \min ^{-1}\right)=\frac{T m-T i}{t}
$$

where $T m$ is the maximum temperature attained by the system, $T i$ is the initial temperature, both in Kelvin, and $t$ is the time in minutes required to reach the maximum temperature.

From the above equation, the inhibition efficiency $(I E)$ of the used inhibitor was computed using equation (2):

$$
I E \%=\frac{R N f-R N i}{R N f} \times 100
$$

where $R N f$ is the reaction number of aqueous acid in the absence of inhibitor, and $R N i$ is the reaction number of aqueous acid in the presence of inhibitor [9, 13, 24].

\section{Results and discussion}

\subsection{Effect of corrodent concentration on the corrosion of aluminium}

Figure 1 presents the variation of temperature with time for the corrosion of aluminium coupons in 0.5 and $1.0 \mathrm{M}$ $\mathrm{HCl}$ respectively. From the plot, it is observed that the dissolution of aluminium starts after a certain time known as the incubation period, from the immersion of the aluminium coupon in the test solution. The incubation time is the time needed by the acid to destroy the pre- immersion oxide film on the surface of the aluminium before a gradual rise in temperature with time to a maximum temperature, $\mathrm{Tm}$. There was a decrease in temperature values after reaching a maximum temperature in the $1.0 \mathrm{M} \mathrm{HCl}$ solution.

From Figure 1, it can be observed that the corrosion of aluminium in $1.0 \mathrm{M} \mathrm{HCl}$ released more heat resulting in a higher value of $\mathrm{Tm}$ of $322 \mathrm{~K}\left(49^{\circ} \mathrm{C}\right)$ at $25 \mathrm{~min}$ compared to a $\mathrm{Tm}$ of $311 \mathrm{~K}\left(38{ }^{\circ} \mathrm{C}\right)$ at $50 \mathrm{~min}$ in $0.5 \mathrm{M}$ $\mathrm{HCl}$. Also, the dissolution of aluminium in $1.0 \mathrm{M} \mathrm{HCl}$ took a shorter time of $25 \mathrm{~min}$ to attain $\mathrm{Tm}$ as against 50 $\min$ in $0.5 \mathrm{M} \mathrm{HCl}$. This is in accordance with the fact that thermodynamically, an increase in $\mathrm{HCl}$ concentration gives rise to a corresponding increase in the concentrations of active species as well as increase in the rate of dissolution of aluminium [9, 13, 24].

The reaction number is directly proportional to the corrosion rate of a metal or alloy [13, 24]. Figure 2 shows that the reaction number of aluminium in $0.5 \mathrm{M} \mathrm{HCI}$ is lower compared its reaction number in 1.0 M HCI. This signifies that an increase in concentration of the corrodent increased the rate of corrosion of aluminum and hence, the reaction number.

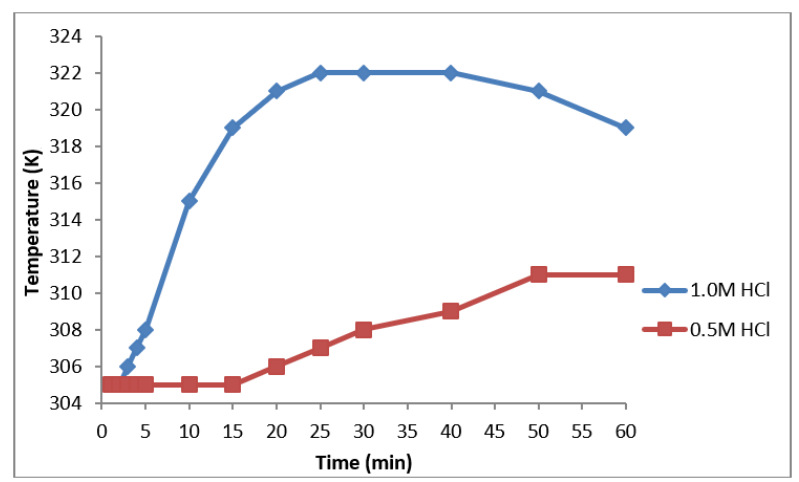

Figure 1. Variation of temperature $(\mathrm{K})$ with time (min) for the corrosion of aluminium coupons in 0.5 and $1.0 \mathrm{M} \mathrm{HCl}$ respectively.

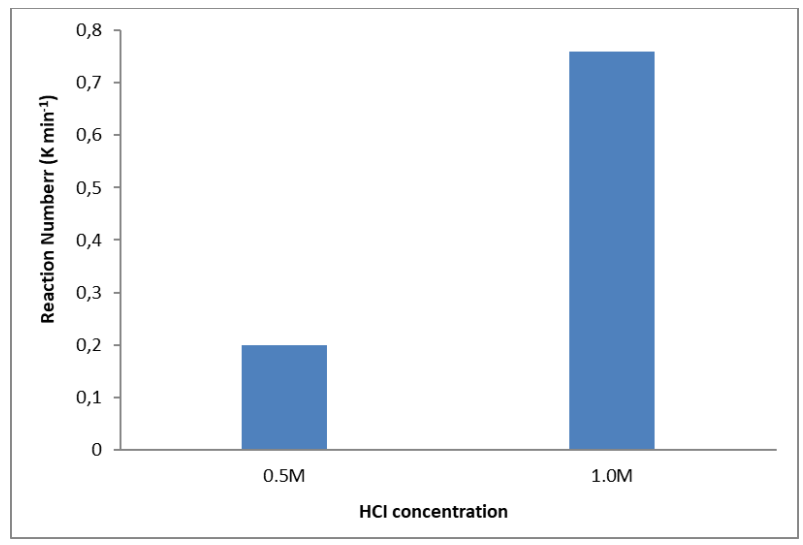

Figure 2. Effect of corrodent concentration on reaction number, $\mathrm{RN}\left(K \cdot \mathrm{min}^{-1}\right)$ for the dissolution of aluminium in $\mathrm{HCl}$.

\subsection{Effect of NI seed extract on the corrosion of aluminium in 0.5 and $1.0 \mathrm{M} \mathrm{HCl}$}

Figures 3 and 4 present the variation of temperature with time for the corrosion of aluminium coupons in the absence and presence of NI extract in 0.5 and $1.0 \mathrm{M} \mathrm{HCl}$ respectively. From the plots, it can be observed that the addition of NI extract to the acid solutions released less 
heat than was observed in the blank solution (absence of $\mathrm{NI}$ ). This is reflected in the lower temperature values that were observed and a decreased in $T m$ values compared to the uninhibited acid solutions. The maximum temperature measured in the uninhibited $0.5 \mathrm{M}$ and 1.0 $\mathrm{M} \mathrm{HCl}$ solutions were $311 \mathrm{~K}\left(38{ }^{\circ} \mathrm{C}\right)$ and $324 \mathrm{~K}\left(51{ }^{\circ} \mathrm{C}\right)$ attained after $40 \mathrm{~min}$ and $25 \mathrm{~min}$ respectively. This corresponds to a $\mathrm{RN}$ of 0.45 and $0.76 \mathrm{~K} / \mathrm{min}$ respectively in both acid concentrations.

Addition of NI extract to the acid solutions caused a decreased in the maximum temperature $(307 \mathrm{~K}$ and 317 $\mathrm{K})$ and an increase in the time required to reach it $(60$ mins for both concentrations). This implies that the dissolution of aluminium coupons in the acid solutions was slowed down on addition of NI extract resulting in the inhibition of the corrosion process. This was possible by the adsorption of the seed extract on the surface of the aluminium coupons thereby blocking further attack by the corrosive species [9-11]. Furthermore, increasing the concentration of NI extract led to a decrease in $\mathrm{Tm}$, the $R N$ of aluminium and an increase in the inhibition efficiency of NI extract in both $0.5 \mathrm{M}$ and $1.0 \mathrm{M} \mathrm{HCl}$ solutions.

Table 1 presents the values of reaction number, inhibition efficiency and surface coverage $(\theta)$ for the dissolution of aluminum in the presence of different concentrations of NI extract in $0.5 \mathrm{M}$ and $1.0 \mathrm{M} \mathrm{HCl}$ respectively.

From the results presented on Table 1, it can be observed that the presence of the NI seed extract reduced the reaction number of aluminium thereby inhibiting the corrosion of aluminium in both 0.5 and $1.0 \mathrm{M} \mathrm{HCl}$ respectively. The inhibition efficiency of the seed extract was concentration dependent. Inhibition efficiency was found to be $66.70 \%$ and $71.05 \%$ at the optimum concentration of $1.0 \mathrm{~g} / \mathrm{L}$ in $0.5 \mathrm{M}$ and $1.0 \mathrm{M} \mathrm{HCl}$ respectively. This suggests that as the concentration of the plant extract increased, there was an increase in surface coverage of the adsorbed extract on the aluminium coupons which provided a barrier and prevented further dissolution. This result is in agreement with previous studies [7-11, 18, 19].
The higher concentration $(1.0 \mathrm{M})$ corrodent, gave better inhibition efficiency values compared to the lower concentration corrodent. This may be due to the presence of more chloride ions which served as a bridge between the aluminium surface and NI extract molecules hence changing the electric double layer interface between the aluminium surface and inhibitor from positive to negative resulting in an enhanced adsorption of NI extract molecules on the aluminium surface $[11,18,25$, 26].

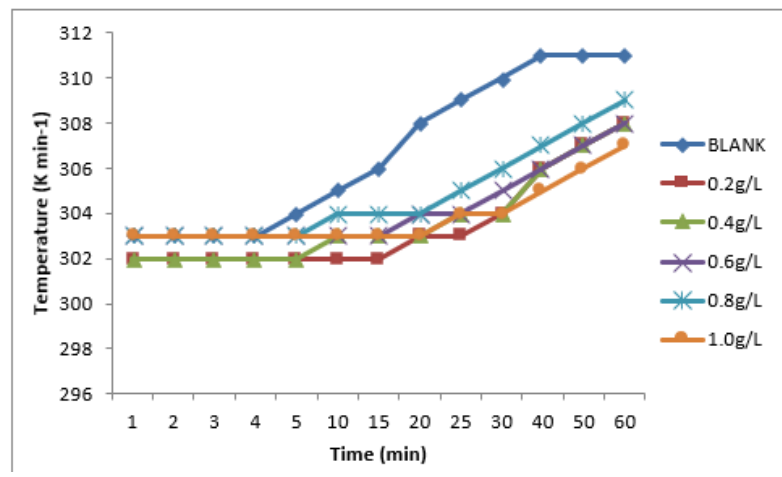

Figure 3. Variation of temperature with time for the corrosion of aluminium in $0.5 \mathrm{M} \mathrm{HCl}$ in various concentrations of NI extract.

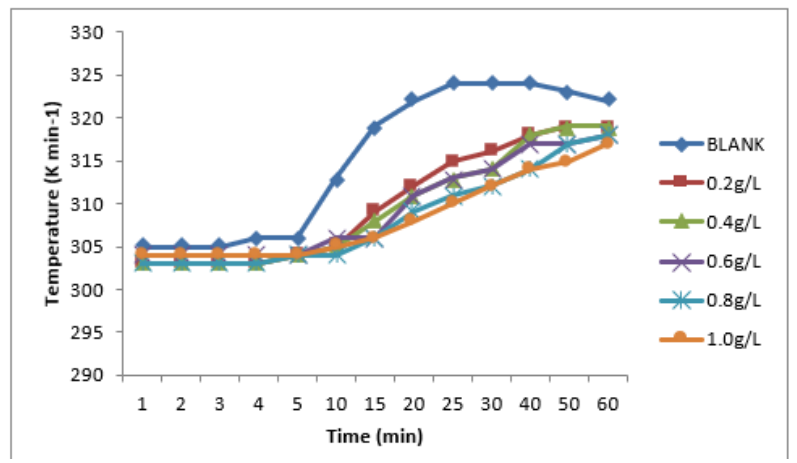

Figure 4. Variation of temperature with time for the corrosion of aluminium in $1.0 \mathrm{M} \mathrm{HCl}$ in various concentrations of $\mathrm{NI}$ extract.

Table 1. Values of reaction number, inhibition efficiency and surface coverage for the corrosion of aluminium in 0.5 and $1.0 \mathrm{M} \mathrm{HCl}$ with various concentrations of NI extract.

\begin{tabular}{|c|c|c|c|c|c|c|}
\hline \multirow[b]{2}{*}{ Concentration } & \multicolumn{2}{|r|}{$R N$} & \multicolumn{2}{|c|}{$I E \%$} & \multicolumn{2}{|r|}{$\boldsymbol{\theta}$} \\
\hline & $0.5 \mathrm{M} \mathrm{HCl}$ & 1.0 M HCl & $0.5 \mathrm{M} \mathrm{HCl}$ & $1.0 \mathrm{M} \mathrm{HCl}$ & $0.5 \mathrm{M} \mathrm{HCl}$ & $1.0 \mathrm{M} \mathrm{HCl}$ \\
\hline Blank & 0.20 & 0.76 & - & - & - & - \\
\hline $0.2 \mathrm{~g} / \mathrm{L}$ & 0.1 & 0.32 & 50.00 & 58.00 & 0.50 & 0.58 \\
\hline $0.4 \mathrm{~g} / \mathrm{L}$ & 0.1 & 0.32 & 50.00 & 58.00 & 0.50 & 0.58 \\
\hline $0.6 \mathrm{~g} / \mathrm{L}$ & 0.0833 & 0.23 & 58.35 & 69.74 & 0.58 & 0.70 \\
\hline $0.8 \mathrm{~g} / \mathrm{L}$ & 0.1 & 0.25 & 50.00 & 67.11 & 0.50 & 0.67 \\
\hline $1.0 \mathrm{~g} / \mathrm{L}$ & 0.0666 & 0.22 & 66.70 & 71.05 & 0.67 & 0.71 \\
\hline
\end{tabular}

\subsection{Effect of KI on the dissolution of aluminium}

Figures 5 and 6 present the variation of temperature with time for the corrosion of aluminium coupons in various concentrations of $\mathrm{KI}$ in 0.5 and $1.0 \mathrm{M} \mathrm{HCl}$ respectively. From the plots, it can be observed that the corrosion of aluminium in the presence of KI gave lower temperature values and $T m$ than the free acid solution. This implies that KI inhibited the corrosion of aluminium in both concentrations of $\mathrm{HCl}$.

Table 2 presents values of reaction number, inhibition efficiency and surface coverage for the corrosion of aluminium in the presence of various concentrations of $\mathrm{KI}$ in 0.5 and $1.0 \mathrm{M} \mathrm{HCl}$ respectively. 


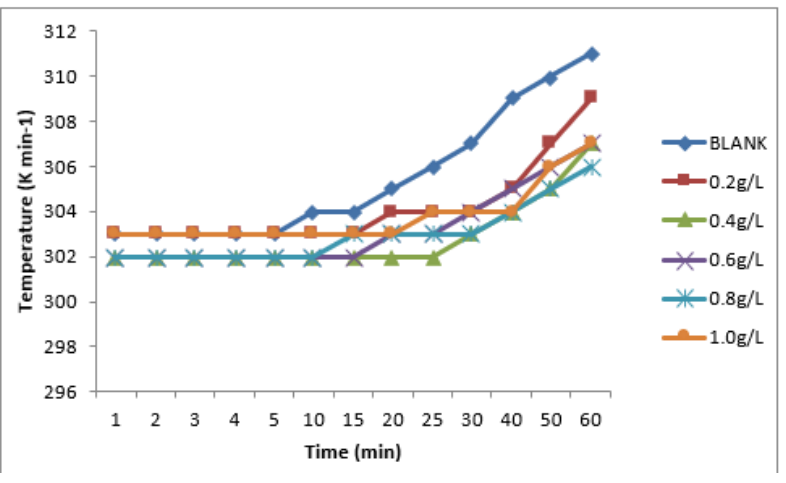

Figure 5. Variation of temperature with time for the corrosion of aluminium in $0.5 \mathrm{M} \mathrm{HCl}$ with various concentrations of $\mathrm{KI}$.

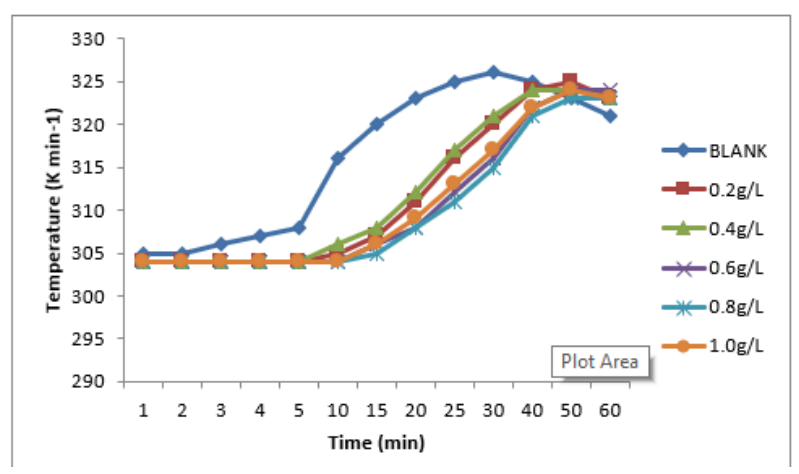

Figure 6. Variation of temperature with time for the corrosion of aluminum in $1.0 \mathrm{M} \mathrm{HCl}$ with various concentrations of $\mathrm{KI}$.

Table 2. Values of reaction number, inhibition efficiency and surface coverage for the corrosion of aluminium in 0.5 and $1.0 \mathrm{M} \mathrm{HCl}$ with various concentrations of $\mathrm{KI}$.

\begin{tabular}{|c|c|c|c|c|c|c|}
\hline \multirow{2}{*}{$\begin{array}{c}\text { Concentration } \\
\text { (M) }\end{array}$} & \multicolumn{2}{|c|}{$R N$} & \multicolumn{2}{|c|}{$I E \%$} & \multicolumn{2}{|c|}{$\theta$} \\
\hline & $0.5 \mathrm{M} \mathrm{HCl}$ & $1.0 \mathrm{M} \mathrm{HCl}$ & $0.5 \mathrm{M} H C l$ & $1.0 \mathrm{M} \mathrm{HCl}$ & $0.5 \mathrm{M} \mathrm{HCl}$ & $1.0 \mathrm{M} \mathrm{HCl}$ \\
\hline Blank & 0.1333 & 0.7 & - & - & - & - \\
\hline 0.001 & 0.1 & 0.42 & 23.08 & 40.00 & 0.23 & 0.40 \\
\hline 0.002 & 0.0833 & 0.50 & 35.92 & 28.57 & 0.36 & 0.29 \\
\hline 0.003 & 0.0833 & 0.40 & 35.92 & 42.86 & 0.36 & 0.43 \\
\hline 0.004 & 0.0666 & 0.38 & 48.77 & 45.71 & 0.49 & 0.46 \\
\hline 0.005 & 0.0666 & 0.40 & 48.77 & 42.86 & 0.49 & 0.43 \\
\hline
\end{tabular}

3.4. Effect of KI and NI seed extract mixture on the corrosion of aluminium

Iodide ion $\left(\mathrm{I}^{-}\right)$is characterized by its strong adsorbability onto the metal surface due to its large ionic radius. This process changes the electrical double layer at the solution side of the interface from positive to negative. This change in the electrical double layer facilitates physical adsorption of the inhibitor cations [25, 26]. Consequently, the protonated phytochemicals in NI extract are able to adsorb electrostatically on the aluminium (electrode) surface covered primarily by adsorbed $\mathrm{I}^{-}$ions.

Figures 7 and 8 present the variation of temperature with time for the corrosion of aluminium coupons in the absence and presence of various concentrations of NI extract and $5 \mathrm{mM} \mathrm{KI}$ solution mixture in 0.5 and $1.0 \mathrm{M}$ $\mathrm{HCl}$ respectively. From the plots, it can be observed that the corrosion of aluminium in the presence of NI extract with $5 \mathrm{mM}$ KI solution gave lower temperature values and $T m$ than the uninhibited solution.

Table 3 presents values of reaction number, inhibition efficiency and surface coverage for the corrosion of aluminum in the presence of various concentrations of NI extract and $5 \mathrm{mM} \mathrm{KI}$ solution in 0.5 and $1.0 \mathrm{M} \mathrm{HCl}$ respectively.

The values of IE presented on Table 3 shows that the inhibition efficiency of NI seed extract and $5 \mathrm{mM} \mathrm{KI}$ mixture were higher at all the concentrations investigated than were obtained for the various concentrations of the seed extract alone (Table 1). This implies that the presence of the iodide ions enhanced the inhibitive and adsorptive behaviour of NI seed extract thereby resulting in higher inhibition efficiency values. Similar results have also been reported by other researchers $[8,13,18$, $25,26]$.

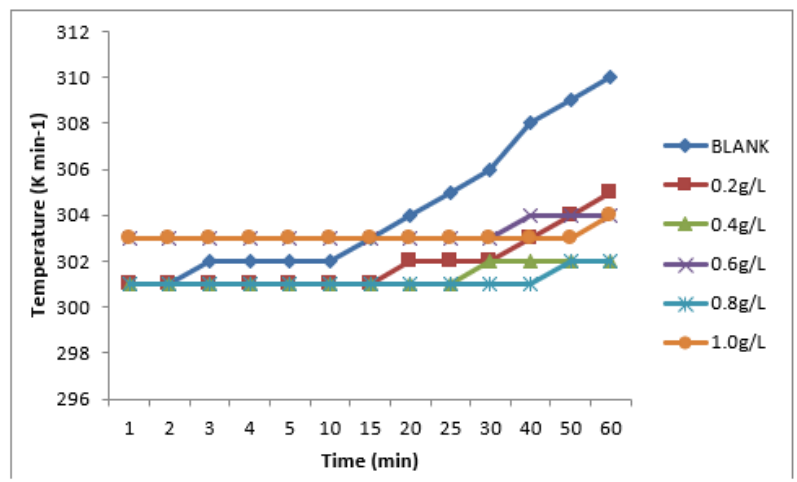

Figure 7. Variation of temperature with time ( $\mathrm{min}$ ) for the dissolution of aluminium in $0.5 \mathrm{M} \mathrm{HCl}$ for various concentrations of NI extract $+5 \mathrm{mM} \mathrm{KI}$.

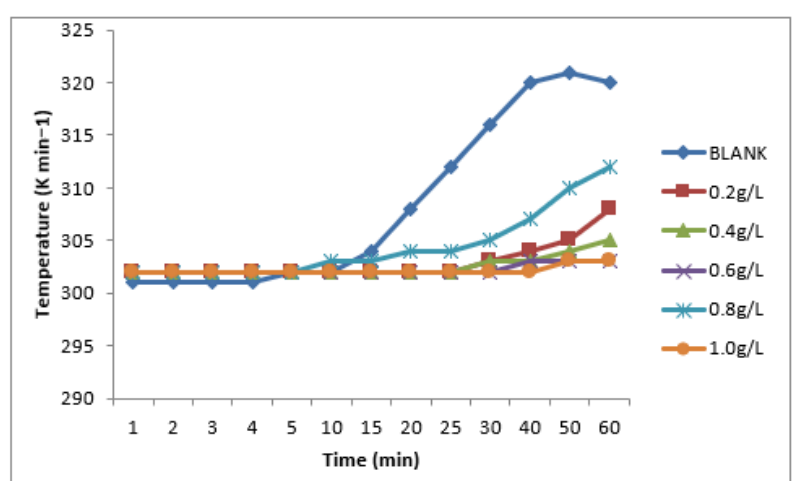

Figure 8. Variation of temperature with time ( $\mathrm{min}$ ) for the dissolution of aluminium in $1.0 \mathrm{M} \mathrm{HCl}$ for various concentrations of NI extract $+5 \mathrm{mM} \mathrm{KI}$. 
Table 3. Values of reaction number, inhibition efficiency and surface coverage, for various concentrations of NI seed extract $+5 \mathrm{mM}$ KI mixtures.

\begin{tabular}{|c|c|c|c|c|c|c|}
\hline \multirow{2}{*}{$\begin{array}{c}\text { Concentration } \\
(\mathrm{g} / \mathrm{L})\end{array}$} & \multicolumn{2}{|c|}{$R N$} & \multicolumn{2}{|c|}{$I E \%$} & \multicolumn{2}{|c|}{$\theta$} \\
\hline & $0.5 \mathrm{M} \mathrm{HCl}$ & $1.0 \mathrm{M} \mathrm{HCl}$ & $0.5 \mathrm{M} \mathrm{HCl}$ & $1.0 \mathrm{M} \mathrm{HCl}$ & $0.5 \mathrm{M} \mathrm{HCl}$ & $1.0 \mathrm{M} \mathrm{HCl}$ \\
\hline Blank & 0.15 & 0.4 & - & - & - & - \\
\hline 0.2 & 0.07 & 0.1 & 53.33 & 75.00 & 0.53 & 0.75 \\
\hline 0.4 & 0.03 & 0.05 & 80.00 & 87.5 & 0.80 & 0.88 \\
\hline 0.6 & 0.025 & 0.025 & 83.33 & 93.75 & 0.83 & 0.94 \\
\hline 0.8 & 0.02 & 0.022 & 86.67 & 94.00 & 0.87 & 0.94 \\
\hline 1.0 & 0.0166 & 0.02 & 88.93 & 95.00 & 0.89 & 0.95 \\
\hline
\end{tabular}

\subsection{Synergism}

Synergism is a combined action of a compound greater in total effect than the sum of individual effects. It has become one of the most important factors in inhibition process and serves as a basis for all modern corrosion inhibitor formulation. Synergism of corrosion inhibitors is either due to interaction between components of the inhibitors or due to interaction between the inhibitor and one of the ions present in aqueous solution $[8,9,13,18$, 25, 26].

Synergistic studies were carried out on the combination of the inhibitor-plant extract $(0.2,0.4,0.6$, $0.8,1.0 \mathrm{~g} / \mathrm{L})$ with $5 \mathrm{mM} \mathrm{KI}$ in $\mathrm{HCl}(0.5 \mathrm{M}, 1.0 \mathrm{M})$ respectively. Synergism parameter $(S)$ of the inhibitor due to halide was calculated using Eq. 3 [8, 9, 13]:

$$
S=\frac{1-I_{A}-I_{B}+I_{A} I_{B}}{1-I_{A B}}
$$

where $I_{\mathrm{A}}$ and $\mathrm{I}_{\mathrm{B}}$ are inhibition efficiencies of the inhibitor and halide, respectively, and $I_{\mathrm{AB}}$ is the inhibition efficiency of the inhibitor, when it is combined with halide. Values of $S$ calculated are recorded in Table 4.

$S$ approaches 1 when no interaction between the inhibitor compounds exists. When $S<1$, the antagonistic interaction prevails, this may be attributed to competitive adsorption $[8,9,13]$. In this study, the values were found to be greater than unity indicating that the adsorption of $\mathrm{KI}$ on the surface of aluminium enhanced the adsorption of Napoleonaea imperialis seed extract on the aluminium surface. From the results obtained (Tables 4), it is obvious that $\mathrm{I}^{-}$ions promoted the physical adsorption of $\mathrm{NI}$ seed extract on the aluminium surface in both $0.5 \mathrm{M}$ and $1.0 \mathrm{M} \mathrm{HCl}$.

Table 4. Synergism parameter for NI extract $+5 \mathrm{mM} \mathrm{KI}$ mixture for the corrosion aluminium in $\mathrm{HCl}$.

\begin{tabular}{cll}
\hline $\begin{array}{c}\text { Concentration of NI } \\
(\mathbf{g} / \mathbf{L})\end{array}$ & \multicolumn{1}{c}{$\mathbf{0 . 5} \mathbf{~ M ~ H C l}$} & $\mathbf{1 . 0} \mathbf{~ M ~ H C l}$ \\
\hline $\mathbf{0 . 0 0}$ & 1 & 1 \\
$\mathbf{0 . 2}$ & 48.47 & 34.94 \\
$\mathbf{0 . 4}$ & 32 & 29.89 \\
$\mathbf{0 . 6}$ & 30.91 & 33.43 \\
$\mathbf{0 . 8}$ & 29.61 & 33.50 \\
$\mathbf{1 . 0}$ & 38.29 & 33.60 \\
\hline
\end{tabular}

\subsection{Adsorption consideration}

Adsorption isotherms provide information about the interaction among adsorbed molecules themselves as well as their interactions with the metal surface. The adsorption characteristics of NI seed extract on the aluminium surface was investigated using different adsorption isotherm models. Assuming a direct relationship between inhibition efficiency and surface coverage, surface coverage values for the various NI concentrations, obtained from the thermometric study were found to align best with the Langmuir adsorption isotherm.

Langmuir adsorption isotherm relates the degree of surface coverage to the concentration of the inhibitor in the bulk electrolyte according to Equation 4:

$$
\frac{C}{\theta}=\frac{1}{k_{a d s}}+C
$$

where $\theta$ is the degree of surface coverage of the inhibitor, $C$ is the concentration of the inhibitor in the bulk electrolyte and $k_{a d s}$ is the adsorption equilibrium constant $[11,27]$.

Figures 9 and 10 show the plots of $\frac{C}{\theta}$ versus concentration for both NI extract and NI + KI. Linear plots were obtained for both plots with the values of $R^{2}$ very close to unity $\left(R^{2}>0.90\right)$.

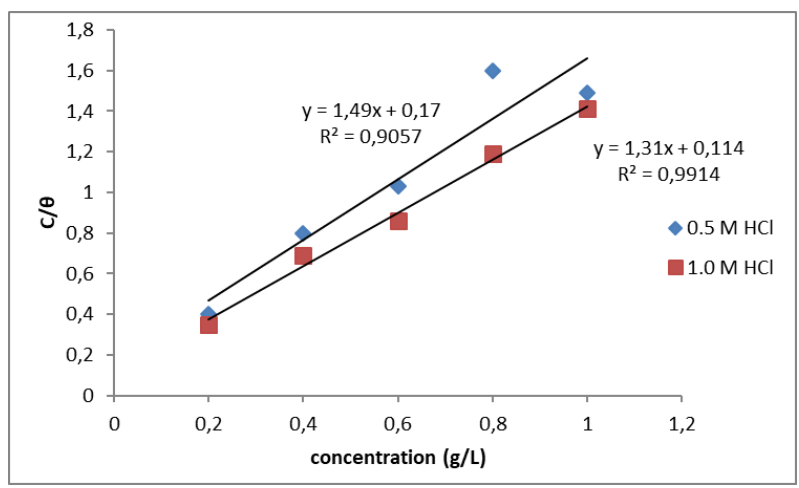

Figure 9. Langmuir plot for the adsorption of NI extract on aluminium surface.

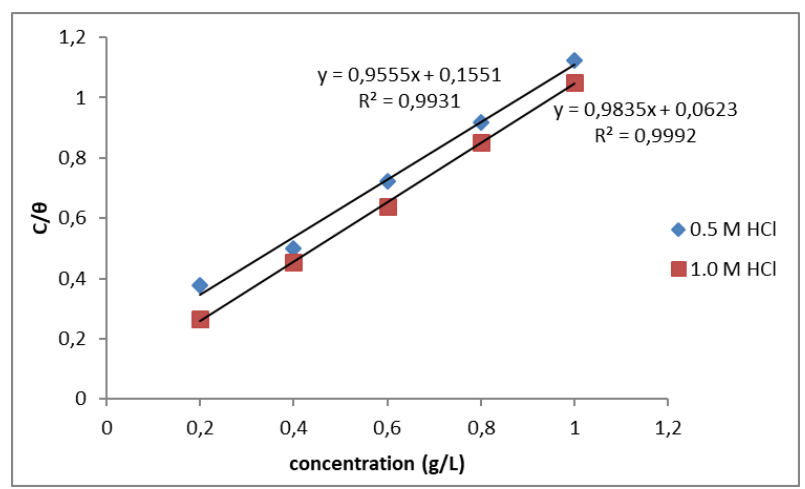

Figure 10. Langmuir plot for the adsorption of NI extract +5 $\mathrm{mM}$ KI on aluminium surface.

The equilibrium constant for adsorption $K_{a d s}$ was evaluated from the intercept of the plots. $K_{a d s}$ is related to the free energy of adsorption according to Eq. 5: 


$$
\Delta G_{a d s}=-2.303 \times R T \log \left(55.5 K_{a d s}\right)
$$

where $K_{a d s}$ is the adsorption equilibrium constant, $R$ is the gas constant (8314 $\left.\mathrm{J} \mathrm{K}^{-1} \mathrm{~mol}^{-1}\right), T$ is the absolute temperature in Kelvin and the value 55.5 is the concentration of water in solution expressed in $\mathrm{mol} \mathrm{L}^{-1}$ $[11,27,28]$. Evaluated values of $K_{a d s}$ and $\Delta G_{a d s}$ are presented on Table 5.

Table 5. Langmuir parameters for the adsorption of $N I$ seed extract on aluminium surface in $0.5 \mathrm{M}$ and $1.0 \mathrm{M} \mathrm{HCl}$ respectively.

\begin{tabular}{|c|c|c|c|c|c|c|}
\hline & $K_{a d s}$ & $R^{2}$ & $\underset{\left(\mathrm{kJ} \cdot \mathrm{mol}^{-1}\right)}{\Delta \boldsymbol{G}_{\boldsymbol{a d s}}}$ & $K_{a d s}$ & $R^{2}$ & $\underset{\left(\mathrm{kJ} \cdot \mathrm{mol}^{-1}\right)}{\Delta \boldsymbol{G}_{\boldsymbol{a d d}}}$ \\
\hline & \multicolumn{3}{|c|}{$0.5 \mathrm{M}$ HCl } & \multicolumn{3}{|c|}{$1.0 \mathrm{M} \mathrm{HCl}$} \\
\hline $\begin{array}{l}\text { NI } \\
\text { NI }\end{array}$ & 5.8823 & 0.905 & -14.34 & 8.7719 & 0.991 & -15.33 \\
\hline $\begin{array}{c}+ \\
\text { KI }\end{array}$ & 6.4516 & 0.993 & -14.57 & 16.1290 & 0.999 & -16.84 \\
\hline
\end{tabular}

The low values of $K_{a d s}$ presented on Table 5 signifies weak interaction between the inhibitor molecules and the aluminium surface while the negative values of $\Delta G_{a d s}$ shows the spontaneous adsorption of NI extract and $\mathrm{NI}+\mathrm{KI}$ on the aluminium surface $[8,9,11,27]$.

Also, values of $\Delta G_{a d s}$ for both NI extract and NI+KI were negatively less than the threshold value of -40 $\mathrm{kJ} \mathrm{mol}^{-1}$ required for the mechanism of chemical adsorption. Thus, the adsorption of NI extract and NI+KI on the aluminium surface is not only spontaneous but is consistent with the electrostatic interaction between charged molecules and the charged metal/alloy surface or physisorption $[8,9,11,18,27,28]$.

\section{Conclusion}

The findings of this study showed that Napoleonaea imperialis seeds extract inhibited the corrosion of aluminium in $0.5 \mathrm{M}$ and $1.0 \mathrm{M} \mathrm{HCl}$ respectively. The inhibition efficiency of NI seed extract was due to the presence of saponins, flavonoids, cardiac glycosides, alkaloids and proteins. The higher the corrodent $(\mathrm{HCl})$ concentration the higher the rate of aluminum corrosion and reaction number. The adsorption of NI seed extract on the aluminium surface was exothermic and spontaneous. The values of the synergistic parameter obtained were found to be greater than unity signifying that the adsorption of the iodide ions on the aluminium surface enhanced the adsorption of NI seed extract on the aluminum surface. The Langmuir isotherm model best described the adsorption of NI seed extract and NI seed extract + KI mixture on the aluminium surface. The adsorptions of NI seed extract and NI + KI mixture on the aluminium surface were spontaneous and physisorptive.

\section{Conflict of interest}

The authors confirm that this article content has no conflicts of interest.

\section{References}

[1]. B. Eker, E. Yuksel, Solutions to corrosion caused by agricultural chemicals, Trakia Journal of Science 3 (2005) 1-6.
[2]. C. Vargel, Corrosion of aluminum. 1st Edn. Elsevier, Amsterdam The Netherlands, 2004.

[3]. V. Shmele, V. Nikolaev, J.H. Lee, C. Yim, Hydrogen production by reaction of aluminum with water, International Journal of Hydrogen Energy 41 (2016) 16664-16673.

[4]. A.M. Mostafa, M.F. Hameed, S.S. Obayya, Effect of laser shock peening on the hardness of AL-7075 alloy, Journal of King Saud University - Science (2017).

[5]. U. Tiringer, I. Milošev, A. Durán, Y. Castro, Hybrid sol-gel coatings based on GPTMS/TEOS containing colloidal $\mathrm{SiO}_{2}$ and cerium nitrate for increasing corrosion protection of aluminium alloy 7075-T6, Journal of Sol-Gel Science and Technology 85 (2018) 546-557.

[6]. F.C. Cambell, Lightweight MaterialsUnderstanding the Basics ASM International, (2012) 33-38.

[7]. I.B. Obot, S.A. Umoren, E.E. Ebenso, N.O. ObiEgbedi, The inhibition of aluminium corrosion in hydrochloric acid solution by exudate gum from Raphia hookeri, Desalination 250 (2009) 225-236.

[8]. S.A. Umoren, I.B. Obot, I.O. Igwe, Synergistic inhibition between polyvinylpyrollidone and iodide ions on corrosion of aluminium in $\mathrm{HCl}$, The Open Corrosion Journal 2 (2009) 1-7.

[9]. I.B. Obot, N.O. Obi-Egbedi, Inhibition of aluminium corrosion in hydrochloric acid using nizoral and the effect of iodide ion addition, EJournal of Chemistry 7 (2010) 837-843.

[10]. L.A. Nnanna, I.U. Anozie, A.G.I. Avoaja, C.S Akoma, E.P. Eti, Comparative study of corrosion inhibition of aluminium alloy of type AA3003 in acidic and alkaline media by Euphorbia hirta extract, African Journal of Pure and Applied Chemistry 5 (2011) 265-271.

[11]. E.E. Oguzie, I.M. Mejeha, M.C. Nwandu, K.B. Okeoma, L.A. Nnanna, M.A. Chidiebere, F.C. Eze, Experimental and theoretical assessment of the inhibiting action of Aspilia africana extract on corrosion of aluminium alloy AA3003 in hydrochloric acid, Journal of Materials Science 47 (2012) 2559-2572.

[12]. A.A. Younis, W. Ensinger, M.M.B. El-Sabbah, R. Holtze, Corrosion protection of pure aluminium and aluminium alloy (AA7075) in salt solution with silane-based sol-gel coatings, Materials and Corrosion 64 (2012) 276-283.

[13]. A.M. Ayuba, A.A. Mustapha, Inhibitive and synergistic properties of ethanolic extract of Anogeissus Leiocarpus leaves on the corrosion of aluminium in $\mathrm{HCl}$ solution, ChemSearch Journal 4 (2013) 55-65.

[14]. A.I. Onen, J. Buba, Ficus polita (Bush fig) leaves extract as corrosion inhibitor of aluminium in alkaline medium, Journal of Chemical Society of Nigeria 43 (2018) 93-102.

[15]. N.O. Eddy, E.E. Ebenso, Adsorption and inhibitive properties of ethanol extract of Musa sapientum peels as a green corrosion inhibitor in acidic medium, African Journal of Pure and Applied Chemistry 2 (2008) 46-84. 
[16]. E.E. Ebenso, N.O. Eddy, A.O. Odiongenyi, Corrosion inhibitive properties and adsorption behaviour of ethanol extract of Piper guinensis as a green corrosion inhibitor for mild steel in $\mathrm{H}_{2} \mathrm{SO}_{4}$, African Journal of Pure and Applied Chemistry 2 (2008) 107-115.

[17]. N.O. Eddy, R.S. Stoyanov, E.E. Ebenso, Fluoroquinolones as corrosion inhibitors for mild steel in acidic medium: Experimental and theoretical studies, International Journal of Electrochemical Science 5 (2010) 1127 - 1150.

[18]. E.E. Oguzie, C.K. Enenebeaku, C.O. Akalezi, S.C. Okoro, A.A. Ayuk, E.N. Ejike, Adsorption and corrosion inhibiting effect of Dacryodis edulis extract on low carbon steel corrosion in acidic media, Journal of Colloid and Interface Science 349 (2010) 283-292.

[19]. E.F. Olasehinde, S.J. Olusegun, A.S. Adesina, S.A. Omogbehin, H. Momoh-Yahaya, Inhibitory action of Nicotiana tabacum extracts on the ccorrosion of mild steel in $\mathrm{HCl}$ : Adsorption and thermodynamics study, Nature and Science 10 (2012) 21-34.

[20]. A.O. James, O. Akaranta, The inhibition of corrosion of zinc in $2.0 \mathrm{M}$ hydrochloric acid solution with acetone extract of red onion skin, African Journal of Pure and Applied Chemistry 3 (2009) 212-217.

[21]. O.K. Abiola, A.O. James, The effects of Aloe vera extract on corrosion and kinetics of corrosion process of zinc in $\mathrm{HCl}$ solution, Corrosion Science 52 (2010) 661-664.

[22]. A.I. Ikeuba, B.I. Ita, R.A. Etiuma, V.M. Bassey, B.U. Ugi, E.B. Kporokpo, Green corrosion inhibitors for mild steel in $\mathrm{H}_{2} \mathrm{SO}_{4}$ solution: Flavonoids of Gongronema latifolium, Chemical and Process Engineering Research 34 (2015) 1-10.

[23]. G.I. Ndukwe, C.M. Ojinnaka, A.O. Oyedeji, Novel bioactive triterpenoid saponin from the fruits of Napoleonaea imperialis P. Beauv (Lecythidaceae), International Journal of Chemical Studies 4 (2016) 80-87.

[24]. A.S. Al Gabera, S.A. Seliman, M. Mourada, Thermometric study of inhibition of aluminium corrosion in hydrochloric acid solution, Qatar University of Science Journal 17 (1997) 81-87.

[25]. E.E. Oguzie, Y. Li, F.H. Wang, Corrosion inhibition and adsorption behaviour of methionine on mild steel in sulphuric acid and synergistic effect of iodide ions, Journal of Colloid and Interface Science 310 (2007) 90-98.

[26]. M.A. Amin, Q. Moshen, A.H. Omar, Synergistic effect of $\mathrm{I}^{-}$ions on the corrosion inhibition of $\mathrm{Al}$ in 1.0 M phosporic acid solutions by purine, Materials Chemistry and Physics 123 (2009) 1023-1035.

[27]. S. Manimegalai, P. Manjula, Thermodynamic and adsorption studies for corrosion inhibition of mild steel in aqueous media by Sargasam swartzii (Brown algae) S., Journal of Material and Environmental Science 6 (2015) 1629-1637.

Received: 10.09 .2018

Received in revised form: 19.10 .2018

Accepted: 21.10.2018 